\title{
Small-Scale Variations in Urban Air Pollution Levels Are Significantly Associated with Premature Births: A Case Study in São Paulo, Brazil
}

\author{
Silvia Regina Dias Medici Saldiva ${ }^{1, * \mathbb{C}}$, Ligia Vizeu Barrozo ${ }^{2,3} \mathbb{C}$, Clea Rodrigues Leone ${ }^{4}$, \\ Marcelo Antunes Failla ${ }^{5}{ }^{\circ}$, Eliana de Aquino Bonilha ${ }^{5}{ }^{\circ}$, Regina Tomie Ivata Bernal ${ }^{6}$, \\ Regiani Carvalho de Oliveira ${ }^{7}(1)$ and Paulo Hilário Nascimento Saldiva ${ }^{3,7}$ \\ 1 Centro de Pesquisa e Desenvolvimento para o SUS, Instituto de Saúde, Secretaria do Estado da Saúde de \\ São Paulo, Rua Santo Antônio, 590-Bela Vista, São Paulo 01314-000, Brazil \\ 2 Departamento de Geografia da Faculdade de Ciências, Letras e Filosofia da Universidade de São Paulo, \\ Cidade Universitária, Av. Prof. Luciano Gualberto-Butantã, São Paulo 05344-020, Brazil; lija@usp.br \\ 3 Instituto de Estudos Avançados da Universidade de São Paulo, Rua da Praça do Relógio, 109 andar Térreo. \\ Cidade Universitária, São Paulo 05508-050, Brazil; pepino@usp.br \\ 4 Departamento de Pediatria da Faculdade de Medicina da Universidade de São Paulo, Av. Dr. Enéas de \\ Carvalho Aguiar, 647-Cerqueira César, São Paulo 05403-000, Brazil; clearleone@uol.com.br \\ 5 Coordenação de Epidemiologia e Informação (CEInfo)—Secretaria Municipal da Saúde de São Paulo, R. \\ General Jardim, 36-5 $5^{\circ}$ andar-Vila Buarque, São Paulo 01223-010, Brazil; \\ marcelofailla@prefeitura.sp.gov.br (M.A.F.); ebonilha@prefeitura.sp.gov.br (E.d.A.B.) \\ 6 Núcleo de Pesquisas Epidemiológicas em Nutrição e Saúde da Faculdade de Saúde Pública da Universidade \\ de São Paulo, Av. Dr. Arnaldo, 715-Cerqueira César, São Paulo 01246-000, Brazil; rbernal@usp.br \\ 7 Laboratório de Poluição Ambiental do Departamento de Patologia da Faculdade de Medicina da \\ Universidade de São Paulo, Av. Dr. Arnaldo, 455-Cerqueira César, São Paulo 01246-903, Brazil; \\ regiani@usp.br \\ * Correspondence: smsaldiva@isaude.sp.gov.br
}

Received: 10 August 2018; Accepted: 5 October 2018; Published: 12 October 2018

\begin{abstract}
Premature birth is the result of a complex interaction among genetic, epigenetic, behavioral, socioeconomic, and environmental factors. We evaluated the possible associations between air pollution and the incidence of prematurity in spatial clusters of high and low prevalence in the municipality of São Paulo. It is a spatial case-control study. The residential addresses of mothers with live births that occurred in 2012 and 2013 were geo-coded. A spatial scan statistical test performed to identify possible low-prevalence and high-prevalence clusters of premature births. After identifying, the spatial clusters were drawn samples of cases and controls in each cluster. Mothers were interviewed face-to-face using questionnaires. Air pollution exposure was assessed by passive tubes $\left(\mathrm{NO}_{2}\right.$ and $\left.\mathrm{O}_{3}\right)$ as well as by the determination of trace elements' concentration in tree bark. Binary logistic regression models were applied to determine the significance of the risk of premature birth. Later prenatal care, urinary infection, and hypertension were individual risk factors for prematurity. Particles produced by traffic emissions (estimated by tree bark accumulation) and photochemical pollutants involved in the photochemical cycle (estimated by $\mathrm{O}_{3}$ and $\mathrm{NO}_{2}$ passive tubes) also exhibited significant and robust risks for premature births. The results indicate that air pollution is an independent risk factor for prematurity.
\end{abstract}

Keywords: premature birth; air pollution; air monitoring; spatial analysis 


\section{Introduction}

Premature birth is the result of a complex interaction among genetic, epigenetic, behavioral, socioeconomic, and environmental factors [1,2]. Prematurity is associated with increased morbidity and mortality in the first year of life $[3,4]$. Published data indicate that prematurity enhances the risk of chronic diseases in adulthood [5] such as type 2 diabetes [6], respiratory disease [7], cardiovascular disease [8], and attention deficit disorders [9].

Exposure to environmental contaminants exhibits associations with premature births [10]. Because of its conspicuous nature, air pollution may be responsible for a considerable attributed fraction of global premature births [11]. Using global satellite-based estimates of exposure, Malley et al. [12] estimated that air pollution is responsible for 2.7 million premature births worldwide. Mechanisms responsible for the effects of air pollution exposure in premature birth are not fully clarified, but the induction of systemic inflammation [13] affects both fetal and placental homeostasis [14-19]. In addition, other determinants of prematurity may vary in space such as socioeconomic status (SES), demographics, housing characteristics, behavioral factors, and accessibility to health care. Thus, broader environmental properties may act to isolate or interact with air pollution to increase susceptibility of pregnant women and, consequently, affect birth outcomes [20-22].

The prevalence of prematurity in Brazil was 12.3\% for the period from 2011 to 2012 [23] and were almost the same as in the Municipality of São Paulo for the period. Generally, premature births were more frequent in deprived areas where several social or environmental risk factors for prematurity co-existed [24]. We reasoned that further information about the role of air pollution in determining premature births could be obtained by evaluating possible associations between air pollution and the incidences of prematurity in spatial clusters of high and low prevalence in São Paulo. In this paper, we report the results of a case-control study conducted in three areas of São Paulo selected based on higher ( 2 spatial clusters) and lower prevalence ( 1 spatial cluster) of premature births using a combination of low-cost techniques designed to characterize the spatial variability of air pollution with high resolution. These results support the concept that particles and the ozone are significant risk factors for premature births in São Paulo.

\section{Subjects and Methods}

\subsection{Definition of the Study}

The present study has a case-control design.

\subsection{Study Location}

The municipality of São Paulo has a population of 12.2 million, which is distributed over 1.5 thousand square kilometers. Similar to other Latin American megacities, São Paulo has sharp social and economic contrasts that affect housing conditions and access to medical care. In the period evaluated in the present study (2012 and 2013), 348,337 live births occurred in São Paulo with an 11.9\% prematurity rate that varied from $8.4 \%$ to $15.9 \%$ across São Paulo's 96 administrative units.

\subsection{Identification of Spatial Clusters of Prematurity}

Data on live births and geo-coded residence addresses of the corresponding mothers were obtained from the Secretary of Health of the Municipality of São Paulo. The gestational period was computed for each live birth based on the mother's day of last menstruation. Clusters of premature births were identified by applying a retrospective spatial scan statistical test using the software SaTScan ${ }^{\mathrm{TM}}$ [25]. To minimize biases induced by grouping large administrative districts, cases were aggregated by using census units as geographic units because they presented significantly smaller and more homogeneous areas. Cluster identification was adjusted for the following covariates: mother's age, type of pregnancy (singleton or multiple), and type of delivery (vaginal or caesarean). Cases were assumed to be poisson distributed with the constant risk over space under the null 
hypothesis in a bi caudal test. The spatial scan statistics arrange a circular window of variable size in the map surface and allows its center to move in such a way that, for a given position and size, the window includes a different set of near neighbors. If the window includes a neighbor centroid, the whole geographic unit is considered and included [25]. Cluster analysis results include spatial clusters with no geographic overlap of clusters allowed and a maximum allowable cluster size of $5 \%$ of the population. Significance was evaluated with Monte Carlo simulation with 999 replications where the null hypothesis of no clusters was rejected at an $\alpha$ level of 0.05 . Such an approach, three clusters were identified with two of them with high prevalence (Tremembé and Pedreira) and one of them with low prevalence (Jardim Ângela) (Figure 1). High spatial clusters had an average radius of $3179 \mathrm{~m}$ from its center and the low cluster had a radius of $4848.7 \mathrm{~m}$. Pedreira's cluster included 2033 cases when 1836.38 were expected and Tremembé's had 1274 cases when 1125.85 were expected. The low cluster in Jardim Ângela had 818 cases when 973.69 were expected.

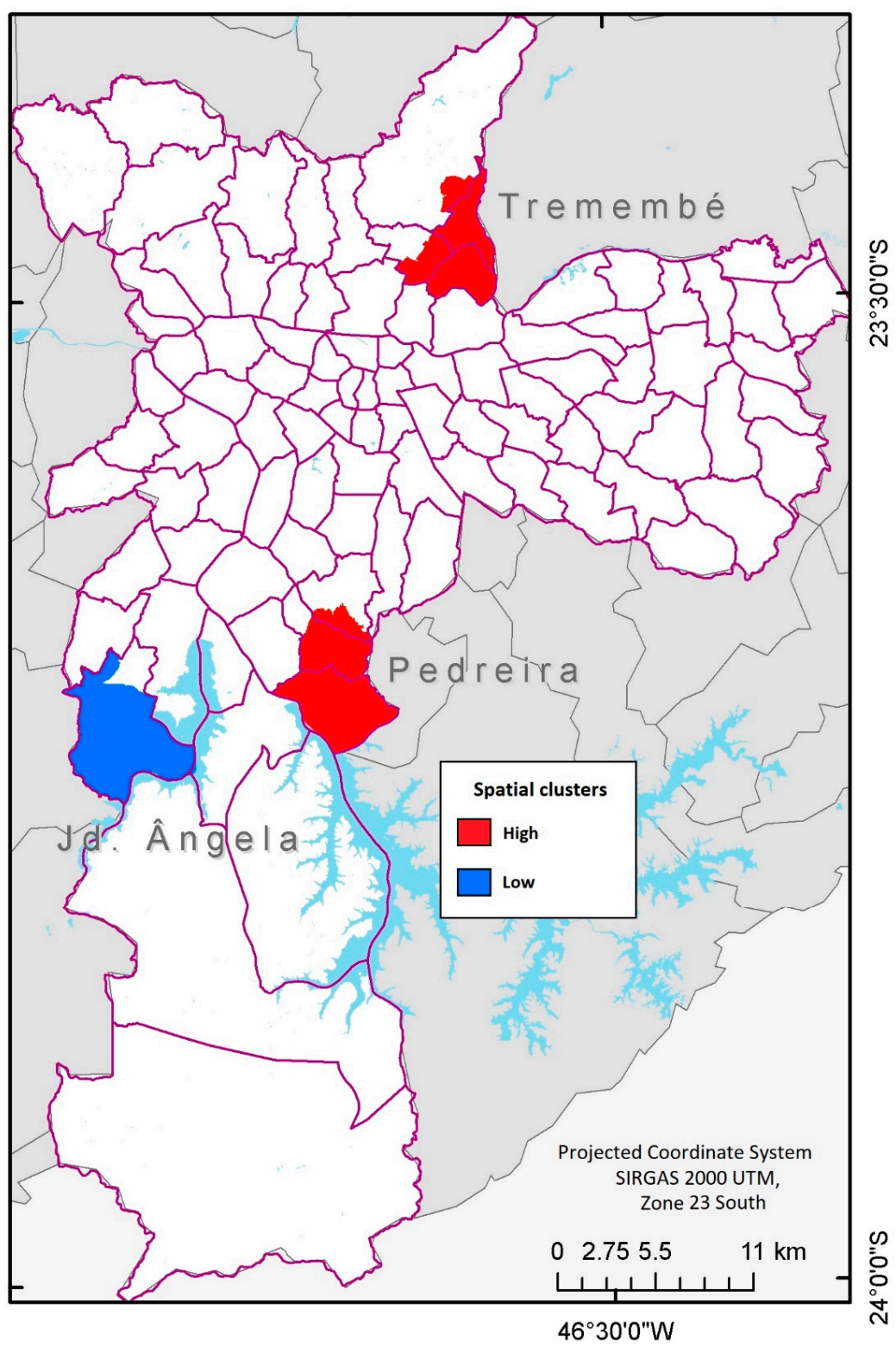

Figure 1. Spatial clusters of preterm deliveries in São Paulo, Brazil (2012-2013). 


\subsection{Definition of Cases and Controls}

Cases were babies born with a gestational age of less than 37 weeks and controls were babies born at a gestational age equal to or more than 37 weeks. The sample was calculated based on the following: a paired study with a proportion of exposure between the cases of $40 \%$, an Odds Ratio of 1.5 with a $10 \%$ significance level, and a power of the test of $80 \%$. These assumptions indicated the necessity of 159 cases and 477 controls. For each case, two controls were randomly selected if they are the same sex and were born in the same or in the following month of cases' date of birth and they lived no more than $400 \mathrm{~m}$ from the corresponding case (Figure 2). The following exclusion criteria were adopted: congenital malformations (Q00-Q99, ICD10, 1994), twins, and indigenous ethnicity.

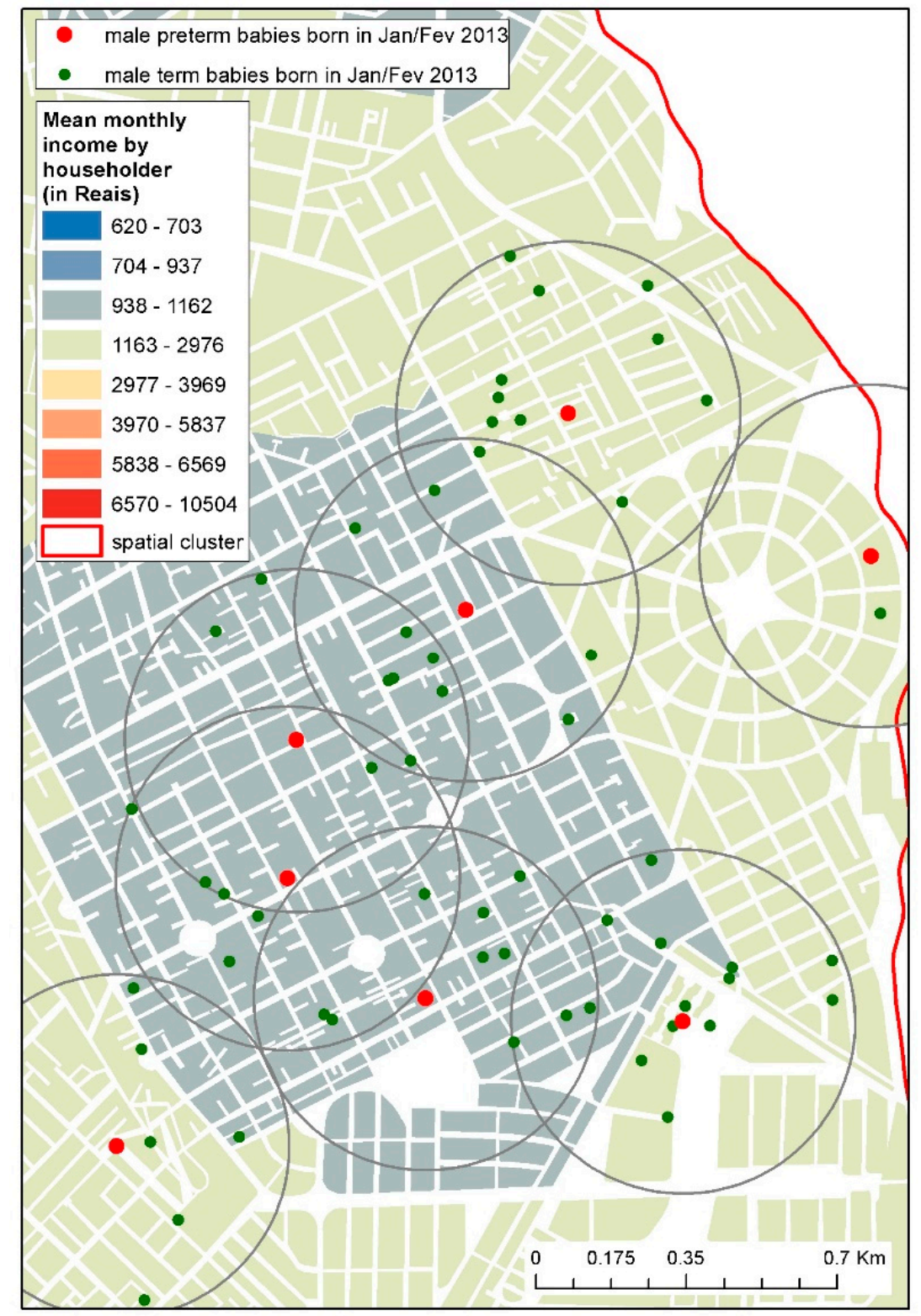

Figure 2. Example of spatial distribution of case-controls. The map depicts male term and preterm babies born in January and February 2013 and a 400 m-buffer from preterm babies overlaid on a map of mean monthly income by householder in a small portion of the municipality. 


\subsection{Variables Related to Mothers}

Since census units were considered the basis for geographic aggregation, secondary census information was included in the modeling such as the average number of residents per household, mean monthly income by householder (in Reais), percentage of households with bathrooms for the exclusive use of residents and sewage via general sewage systems, and percentage of dwellers according to ethnicity (black, mixed-race, and indigenous). Additionally, mothers were interviewed face-to-face by trained interviewers using questionnaires to gather personal information such as schooling, housing, employment, gestational history, pre-natal care, birth care, risk behavior for smoking, alcohol and drugs, and the presence of chronic disease. The interviews were based on five blocks comprising approximately 200 questions.

\subsection{Estimates of Air Pollution Exposure}

Two approaches were used to characterize exposure to air contaminants: passive tubes and the determination of trace element accumulation in tree bark. Passive tubes were used to measure nitrogen dioxide $\left(\mathrm{NO}_{2}\right)$ and ozone $\left(\mathrm{O}_{3}\right)$. The first pollutant is considered a proxy estimator of the gaseous component of fossil fuel burning while $\mathrm{O}_{3}$ reflects gaseous oxidants produced by photochemical processes. $\mathrm{NO}_{2}$ tubes were produced using filters impregnated with $2 \%$ triethanolamine, $0.05 \%$ o-metoxiphenol, and $0.025 \%$ sodium methabisulfite. The reaction with $\mathrm{NO}_{2}$ produced nitrite, which was measured by absorbance at $550 \mathrm{~nm}$. For $\mathrm{O}_{3}$ measurements, we used cellulose filters impregnated with indigo carmine. After reacting with oxidants, the indigo was oxidized to isatin, which faded its blue coloration. The change in color was measured by optical reflectance. Filters in quadruplicate for each site were exposed for seven to 10 days, which provided the average concentration of the two pollutants in the time window of measurement. These two approaches were used by our group in previous field studies and exhibited good agreement with the same measures conducted by the State Sanitation Agency of São Paulo [26,27]. For each cluster, 10 filters were placed following a criterion of the proximity of cases/controls, which is shown in Figure 3. Measurements in each cluster were taken on four separate occasions that represented each season.

Trace elements in tree bark are indicative of particulate air pollution. This approach has previously been used in São Paulo and successfully provided small-scale discrimination of spatial variability of traffic-derived air pollution [28-30] as well as its source apportionment [21]. Particles emitted by pollution sources were trapped in the bark and represented a memory of particulate pollution that lasted for two years. Fragments of tree bark were collected and transformed into powder, the powder was compressed to form pastilles, and the pastilles were then analyzed by $\mathrm{X}$-ray fluorescence spectroscopy. This was a multi-element procedure that allowed measurements of $\mathrm{Al}, \mathrm{Ba}, \mathrm{Ca}, \mathrm{Cl}$, $\mathrm{Cu}, \mathrm{Fe}, \mathrm{K}, \mathrm{Mg}, \mathrm{Mn}, \mathrm{Na}, \mathrm{P}, \mathrm{R}, \mathrm{S}, \mathrm{Sr}$, and $\mathrm{Zn}$.

Based on the verification of existing trees in the areas of study, we collected samples from Tipuana tipu, Caesalpinia pluviosa, Tibouchina granulosa, and Eucalyptus sp. Similar to the passive tubes, 10 trees were sampled in each cluster.

Filters and trees were geo-coded and the attributed dose for each residence was extrapolated by using a quadratic spline based on the Euclidean distance between the residence and the spot of the air pollution measurement. In the statistical modeling, estimates of air pollution (passive tubes and tree bark bio-accumulation of trace elements) were considered categorical variables based on quartiles of the observed extrapolated dose for each child. For the passive tube measurements, the numerical values of the estimated concentration were used. For tree bark bio-accumulation, the elements were not considered individually. Rather, the coefficients of each factor attributed to every child were used. 


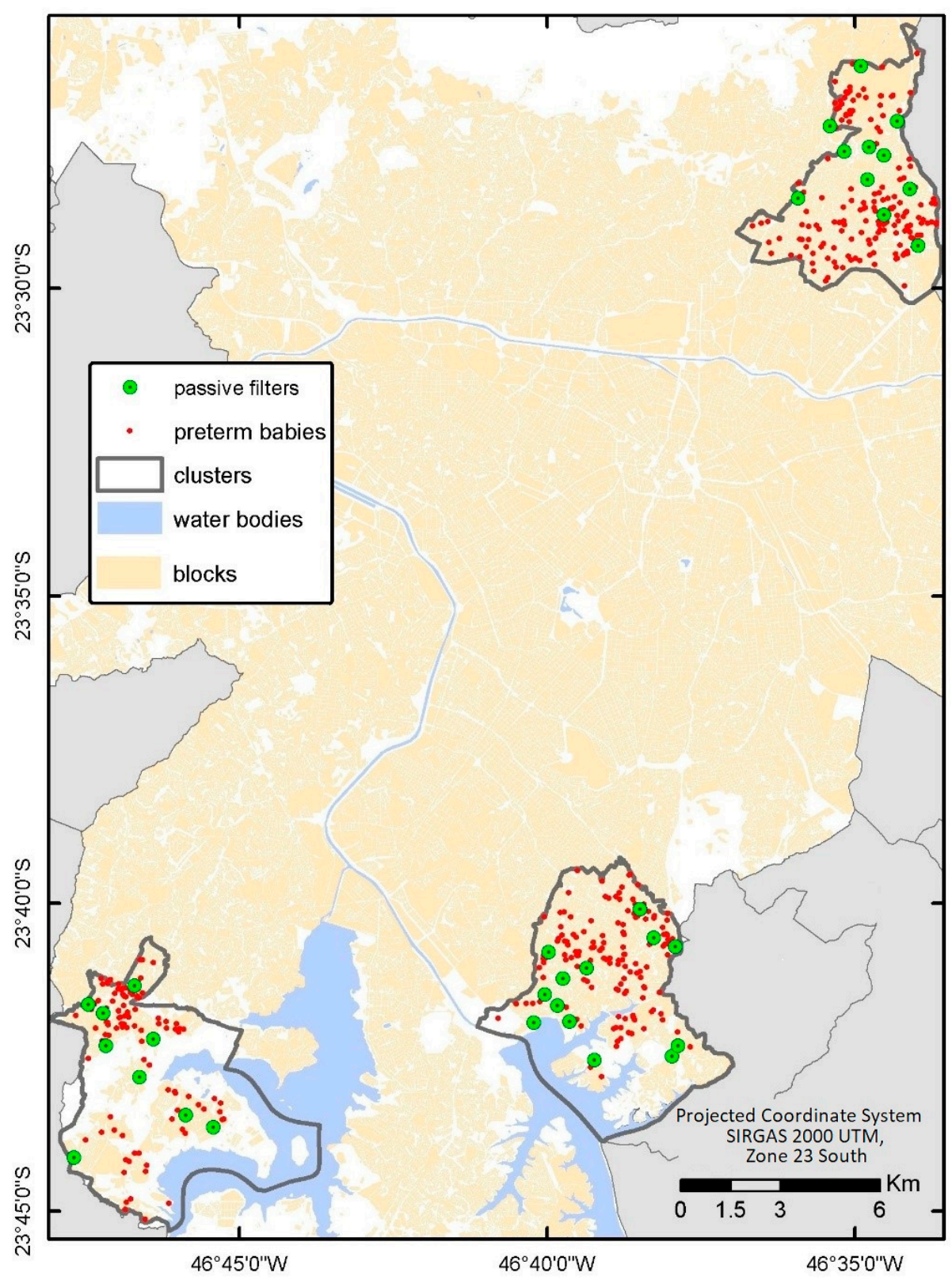

Figure 3. Spatial distribution of filters and interviewed preterm mothers in the studied clusters.

\subsection{Statistical Analysis}

We used different statistical approaches. Geostatistical methods were described above. Factor analysis was used to group the elements measured in tree bark. Different sets of the considered elements were used to obtain the highest explained variance using the Varimax rotation. Descriptive statistics for the characteristics of the study population as well as a comparison between premature and term births among clusters were performed using univariate statistics. The significance of the risk of premature birth was determined by using binary logistic regression models that considered different sets of explanatory variables selected based on their significance detected in the univariate analysis. Although smoking did not reach statistical significance in the univariate models, it was included in the analysis because of the evidence in the literature on its role in favoring premature births. Calculations were performed using Excel v.10 (Microsoft, Redmond, WA, USA) and IBM SPSS v.13 (IBM Corporation, Armonk, NY, USA)for windows packages. Spatial analysis and mapping were performed using ESRI ArcGIS 10.1 (Esri, Redlands, CA, USA). 


\section{Results}

The majority of the cases selected for the Tremembe cluster (110\%) and Pedreira (96\%) were studied and the lowest rate of success was achieved for Jardim Ângela $(69 \%)$ mostly because of improper addresses (high relocation rates of the mothers) and other problems of access such as criminality. These three areas are, in fact, among the most deprived districts of São Paulo in terms of socio-economic indicators. The ratio between controls and cases in the three clusters was around 2:1.

Table 1 presents a summary of the characteristics of the mothers for each cluster and the statistical significance between premature and term births. Jardim Ângela had a high percentage of teenage mothers with premature babies $(10 \%)$, which was higher than the other two clusters, and a high percentage of mothers without partners (35.5\%). A high percentage of premature births for mothers with high levels of education were found in the Tremembé district.

Table 1. Distribution of the characteristics of the mothers in each cluster. The $p$ values depicted in the first column represent the level of significance of the differences between preterm and term births.

\begin{tabular}{|c|c|c|c|c|c|c|}
\hline \multirow{2}{*}{ Clusters } & \multirow{2}{*}{$\begin{array}{c}\text { Mother's } \\
\text { Characteristics }\end{array}$} & \multicolumn{5}{|c|}{ Preterm } \\
\hline & & No & $\%$ & Yes & $\%$ & Total \\
\hline \multirow{3}{*}{$\begin{array}{l}\text { Tremembé } \\
\text { Age }\end{array}$} & $<20 y$ & 10 & 2.8 & 7 & 4.0 & 17 \\
\hline & $20-34.9 y$ & 256 & 71.7 & 113 & 64.2 & 369 \\
\hline & $\geq 35 y$ & 91 & 25.5 & 56 & 31.8 & 147 \\
\hline$p=0.2$ & Total & 357 & 100 & 176 & 100 & 533 \\
\hline \multirow{6}{*}{$\begin{array}{c}\text { Ethnicity } \\
p=0.3\end{array}$} & White & 175 & 49.0 & 76 & 43.2 & 251 \\
\hline & Black & 48 & 13.4 & 21 & 11.9 & 69 \\
\hline & Asian & 3 & 0.8 & 0 & 0 & 3 \\
\hline & Mixed & 125 & 35.0 & 77 & 43.8 & 202 \\
\hline & Indigenous & 6 & 1.7 & 2 & 1.1 & 8 \\
\hline & Total & 357 & 100 & 176 & 100 & 533 \\
\hline \multirow{4}{*}{$\begin{array}{l}\text { Education } \\
p=0.01\end{array}$} & Elementary & 92 & 25.8 & 30 & 17.1 & 122 \\
\hline & High school & 203 & 56.9 & 99 & 56.6 & 302 \\
\hline & College & 62 & 17.4 & 46 & 26.3 & 108 \\
\hline & Total & 357 & 100 & 175 & 100 & 532 \\
\hline \multirow{3}{*}{$\begin{array}{c}\text { Civil status } \\
\quad p=0.2\end{array}$} & Single & 94 & 26.3 & 53 & 30.1 & 147 \\
\hline & Married & 263 & 73.6 & 123 & 69.9 & 386 \\
\hline & Total & 357 & 100 & 176 & 100 & 533 \\
\hline \multirow{4}{*}{$\begin{array}{l}\text { Residence time } \\
\qquad p=0.28\end{array}$} & $<1$ year & 73 & 20.6 & 36 & 20.5 & 109 \\
\hline & $1-5$ years & 130 & 36.6 & 76 & 43.2 & 206 \\
\hline & $\geq 5$ years & 152 & 42.8 & 64 & 36.4 & 216 \\
\hline & Total & 355 & 100 & 176 & 100 & 531 \\
\hline Pedreira & $<20 y$ & 21 & 5.9 & 7 & 4.5 & 28 \\
\hline \multirow{3}{*}{$\begin{array}{c}\text { Age } \\
p=0.8\end{array}$} & $20-34.9 y$ & 234 & 66.1 & 101 & 66.0 & 335 \\
\hline & $\geq 35 y$ & 99 & 27.9 & 45 & 29.4 & 144 \\
\hline & Total & 354 & 100 & 153 & 100 & 507 \\
\hline \multirow{6}{*}{$\begin{array}{l}\text { Ethnicity } \\
p=0.57\end{array}$} & White & 124 & 40.1 & 67 & 45.0 & 191 \\
\hline & Black & 65 & 21.0 & 27 & 18.1 & 92 \\
\hline & Asian & 2 & 0.6 & 0 & 0 & 2 \\
\hline & Mixed & 118 & 38.2 & 55 & 36.9 & 173 \\
\hline & Indigenous & 0 & 0 & 0 & 0 & 0 \\
\hline & Total & 309 & 100 & 149 & 100 & 458 \\
\hline \multirow{4}{*}{$\begin{array}{l}\text { Education } \\
p=0.87\end{array}$} & Elementary & 94 & 26.6 & 38 & 25.0 & 132 \\
\hline & High school & 205 & 57.9 & 88 & 56.6 & 293 \\
\hline & College & 55 & 15.5 & 26 & 17.1 & 81 \\
\hline & Total & 354 & 100 & 152 & 100 & 506 \\
\hline
\end{tabular}


Table 1. Cont.

\begin{tabular}{|c|c|c|c|c|c|c|}
\hline \multirow{2}{*}{ Clusters } & \multirow{2}{*}{$\begin{array}{c}\text { Mother's } \\
\text { Characteristics }\end{array}$} & \multicolumn{5}{|c|}{ Preterm } \\
\hline & & No & $\%$ & Yes & $\%$ & Total \\
\hline \multirow{3}{*}{$\begin{array}{l}\text { Civil status } \\
p=0.63\end{array}$} & Single & 129 & 36.4 & 50 & 32.7 & 179 \\
\hline & Married & 225 & 63.6 & 103 & 67.3 & 328 \\
\hline & Total & 354 & 100 & 153 & 100 & 507 \\
\hline \multirow{4}{*}{$\begin{array}{l}\text { Residence time } \\
\qquad p=0.25\end{array}$} & $<1$ year & 32 & 9.2 & 21 & 13.8 & 53 \\
\hline & $1-5$ years & 138 & 39.5 & 61 & 40.1 & 199 \\
\hline & $\geq 5$ years & 179 & 51.3 & 70 & 46.1 & 249 \\
\hline & Total & 349 & 100 & 152 & 100 & 501 \\
\hline Jardim Ângela & $<20 y$ & 8 & 3.0 & 11 & 10.1 & 19 \\
\hline \multirow{3}{*}{$\begin{array}{c}\text { Age } \\
p=0.02\end{array}$} & $20-34.9 y$ & 192 & 72.5 & 75 & 68,8 & 267 \\
\hline & $\geq 35 y$ & 65 & 24.5 & 23 & 21.1 & 88 \\
\hline & Total & 265 & 100 & 110 & 100 & 374 \\
\hline \multirow{6}{*}{$\begin{array}{l}\text { Ethnicity } \\
p=0.63\end{array}$} & White & 91 & 34.3 & 31 & 28.2 & 122 \\
\hline & Black & 27 & 10.2 & 15 & 13.8 & 42 \\
\hline & Asian & 1 & 0.4 & 1 & 0.9 & 2 \\
\hline & Mixed & 145 & 54.7 & 61 & 56.0 & 207 \\
\hline & Indigenous & 1 & 0.4 & 1 & 0.9 & 2 \\
\hline & Total & 265 & 100 & 109 & 100 & 374 \\
\hline \multirow{4}{*}{$\begin{array}{l}\text { Education } \\
p=0.43\end{array}$} & Elementary & 56 & 21.4 & 28 & 25.9 & 84 \\
\hline & High school & 163 & 62.2 & 67 & 62.0 & 230 \\
\hline & College & 43 & 16.4 & 13 & 12.0 & 56 \\
\hline & Total & 262 & 100 & 108 & 100 & 370 \\
\hline \multirow{3}{*}{$\begin{array}{l}\text { Civil status } \\
\qquad p=0.03\end{array}$} & Single & 75 & 28.3 & 39 & 35.8 & 114 \\
\hline & Married & 190 & 71.7 & 70 & 64.2 & 260 \\
\hline & Total & 265 & 100 & 109 & 100 & 374 \\
\hline \multirow{4}{*}{$\begin{array}{l}\text { Residence time } \\
\qquad p=0.21\end{array}$} & $<1$ year & 34 & 12.8 & 21 & 19.3 & 55 \\
\hline & $1-5$ years & 122 & 46.0 & 42 & 38.5 & 164 \\
\hline & $\geq 5$ years & 109 & 41.1 & 46 & 42.2 & 155 \\
\hline & Total & 265 & 100 & 109 & 100 & 374 \\
\hline
\end{tabular}

Table 2 shows the characteristics of prenatal assistance in each cluster as well as the statistical significance between premature and term births. Mothers with preterm labor in the Pedreira district started prenatal care later $(18.4 \%)$ and had a higher incidence of urinary infection $(68.5 \%)$ and hypertension $(63.2 \%)$ than mothers with term births had.

Table 2. Distribution of prenatal characteristics in each cluster. The $p$ values depicted in the first column represent the level of significance of the differences between preterm and term births.

\begin{tabular}{ccccccc}
\hline \multirow{2}{*}{ Clusters } & Prenatal & \multicolumn{5}{c}{ Preterm } \\
\cline { 3 - 7 } & Characteristics & No & \% & Yes & $\%$ & Total \\
\hline Tremembé & 1 trimester & 310 & 87.6 & 151 & 87.7 & 461 \\
Beginning & 2 trimester & 39 & 11.0 & 17 & 9.9 & 56 \\
prenatal care & 3 trimester & 5 & 1.4 & 4 & 2.3 & 9 \\
$p=0.7$ & Total & 354 & 100 & 172 & 100 & 526 \\
\hline \multirow{2}{*}{ Formal work } & Yes & 198 & 55.8 & 95 & 54.0 & 293 \\
$p=0.38$ & No & 157 & 42.2 & 81 & 46.0 & 238 \\
& Total & 355 & 100 & 176 & 100 & 531 \\
\hline Public & Yes & 250 & 70.6 & 113 & 64.2 & 363 \\
assistance & No & 104 & 29.4 & 63 & 35.8 & 167 \\
$p=0.08$ & Total & 354 & 100 & 176 & 100 & 530 \\
\hline
\end{tabular}


Table 2. Cont.

\begin{tabular}{|c|c|c|c|c|c|c|}
\hline \multirow{2}{*}{ Clusters } & \multirow{2}{*}{$\begin{array}{c}\text { Prenatal } \\
\text { Characteristics }\end{array}$} & \multicolumn{5}{|c|}{ Preterm } \\
\hline & & No & $\%$ & Yes & $\%$ & Total \\
\hline \multirow{3}{*}{$\begin{array}{c}\text { Number of } \\
\text { consultations } \\
p=0.39\end{array}$} & $<7$ & 74 & 21.1 & 39 & 22.5 & 113 \\
\hline & $\geq 7$ & 277 & 78.9 & 134 & 77.5 & 411 \\
\hline & Total & 351 & 100 & 173 & 100 & 524 \\
\hline \multirow{3}{*}{$\begin{array}{c}\text { Urinary } \\
\text { infection } \\
p=0.91\end{array}$} & Yes & 206 & 58.0 & 103 & 58.5 & 309 \\
\hline & No & 149 & 42.0 & 73 & 41.5 & 222 \\
\hline & Total & 355 & 100 & 176 & 100 & 531 \\
\hline \multirow{3}{*}{$\begin{array}{l}\text { Hypertension } \\
\qquad p=0.12\end{array}$} & Yes & 52 & 14.6 & 35 & 19.9 & 87 \\
\hline & No & 303 & 85.4 & 141 & 80.1 & 444 \\
\hline & Total & 355 & 100 & 176 & 100 & 531 \\
\hline \multirow{3}{*}{$\begin{array}{l}\text { Type of } \\
\text { delivery } \\
p=0.2\end{array}$} & Vaginal & 171 & 48.0 & 92 & 52.3 & 263 \\
\hline & C-section & 185 & 52.0 & 84 & 47.7 & 269 \\
\hline & Total & 356 & 100 & 176 & 100 & 532 \\
\hline \multirow{4}{*}{$\begin{array}{l}\text { Pedreira } \\
\text { Beginning } \\
\text { prenatal care } \\
\quad p=0.01\end{array}$} & 1 trimester & 304 & 91.8 & 124 & 81.6 & 428 \\
\hline & 2 trimester & 26 & 7.9 & 23 & 15.1 & 49 \\
\hline & 3 trimester & 1 & 0.3 & 5 & 3.3 & 6 \\
\hline & Total & 331 & 100 & 152 & 100 & 483 \\
\hline \multirow{3}{*}{$\begin{array}{l}\text { Formal work } \\
\qquad p=0.53\end{array}$} & Yes & 177 & 50.7 & 77 & 50.7 & 254 \\
\hline & No & 172 & 49.3 & 75 & 49.3 & 247 \\
\hline & Total & 349 & 100 & 152 & 100 & 501 \\
\hline \multirow{3}{*}{$\begin{array}{c}\text { Public } \\
\text { assistance } \\
p=0.12\end{array}$} & Yes & 247 & 70.2 & 115 & 75.7 & 362 \\
\hline & No & 105 & 29.8 & 37 & 24.3 & 142 \\
\hline & Total & 352 & 100 & 152 & 100 & 504 \\
\hline \multirow{3}{*}{$\begin{array}{c}\text { Number of } \\
\text { consultations } \\
p=0.53\end{array}$} & $<7$ & 89 & 25.5 & 38 & 25.3 & 127 \\
\hline & $\geq 7$ & 260 & 74.5 & 112 & 74.7 & 372 \\
\hline & Total & 349 & 100 & 150 & 100 & 499 \\
\hline \multirow{3}{*}{$\begin{array}{l}\text { Urinary } \\
\text { infection } \\
p=0.001\end{array}$} & Yes & 29 & 8.3 & 63 & 41.4 & 92 \\
\hline & No & 320 & 91.7 & 89 & 58.6 & 409 \\
\hline & Total & 349 & 100 & 152 & 100 & 501 \\
\hline \multirow{3}{*}{$\begin{array}{l}\text { Hypertension } \\
p=0.0001\end{array}$} & Yes & 21 & 6.0 & 36 & 23.7 & 57 \\
\hline & No & 328 & 94.0 & 116 & 76.3 & 444 \\
\hline & Total & 349 & 100 & 152 & 100 & 501 \\
\hline \multirow{3}{*}{$\begin{array}{l}\text { Type of } \\
\text { delivery } \\
p=0.32\end{array}$} & Vaginal & 197 & 55.6 & 81 & 52.9 & 278 \\
\hline & C-section & 157 & 44.4 & 72 & 47.1 & 229 \\
\hline & Total & 354 & 100 & 153 & 100 & 507 \\
\hline \multirow{4}{*}{$\begin{array}{c}\text { Jardim } \\
\text { Ângela } \\
\text { Beginning } \\
\text { prenatal care } \\
p=0.18\end{array}$} & 1 trimester & 241 & 90.9 & 93 & 86.1 & 334 \\
\hline & 2 trimester & 22 & 8.3 & 15 & 13.9 & 37 \\
\hline & 3 trimester & 2 & 0.8 & 0 & 0 & 2 \\
\hline & Total & 265 & 100 & 108 & 100 & 373 \\
\hline \multirow{3}{*}{$\begin{array}{l}\text { Formal work } \\
\qquad p=0.41\end{array}$} & Yes & 112 & 42.3 & 44 & 40.4 & 156 \\
\hline & No & 153 & 57.7 & 65 & 59.6 & 218 \\
\hline & Total & 265 & 100 & 109 & 100 & 374 \\
\hline \multirow{3}{*}{$\begin{array}{c}\text { Public } \\
\text { assistance } \\
p=0.02\end{array}$} & Yes & 168 & 63.6 & 82 & 75.2 & 250 \\
\hline & No & 96 & 36.4 & 27 & 24.8 & 123 \\
\hline & Total & 264 & 100 & 109 & 100 & 373 \\
\hline \multirow{3}{*}{$\begin{array}{l}\text { Number of } \\
\text { consultations } \\
p=0.43\end{array}$} & $<7$ & 53 & 20.0 & 20 & 18.5 & 73 \\
\hline & $\geq 7$ & 212 & 80.0 & 88 & 81.5 & 300 \\
\hline & Total & 265 & 100 & 108 & 100 & 373 \\
\hline \multirow{3}{*}{$\begin{array}{c}\text { Urinary } \\
\text { infection } \\
p=0.44\end{array}$} & Yes & 155 & 58.5 & 59 & 54.1 & 214 \\
\hline & No & 110 & 41.5 & 50 & 45.9 & 160 \\
\hline & Total & 265 & 100 & 109 & 100 & 374 \\
\hline
\end{tabular}


Table 2. Cont

\begin{tabular}{ccccccc}
\hline \multirow{2}{*}{ Clusters } & Prenatal & \multicolumn{5}{c}{ Preterm } \\
\cline { 3 - 7 } & Characteristics & No & \% & Yes & \% & Total \\
\hline \multirow{2}{*}{$\begin{array}{c}\text { Hypertension } \\
p=0.97\end{array}$} & Yes & 46 & 17.4 & 19 & 17.4 & 65 \\
& No & 219 & 82.6 & 90 & 82.6 & 309 \\
& Total & 265 & 100 & 109 & 100 & 374 \\
\hline Type of & Vaginal & 126 & 47.5 & 55 & 50.5 & 181 \\
delivery & C-section & 139 & 52.5 & 54 & 49.5 & 193 \\
$p=0.34$ & Total & 265 & 100 & 109 & 100 & 374 \\
\hline
\end{tabular}

Figure 4 shows the estimated dose of $\mathrm{NO}_{2}$ and $\mathrm{O}_{3}$ for mothers enrolled in the study. Table 3 shows the descriptive statistics of trace element levels determined in tree bark.
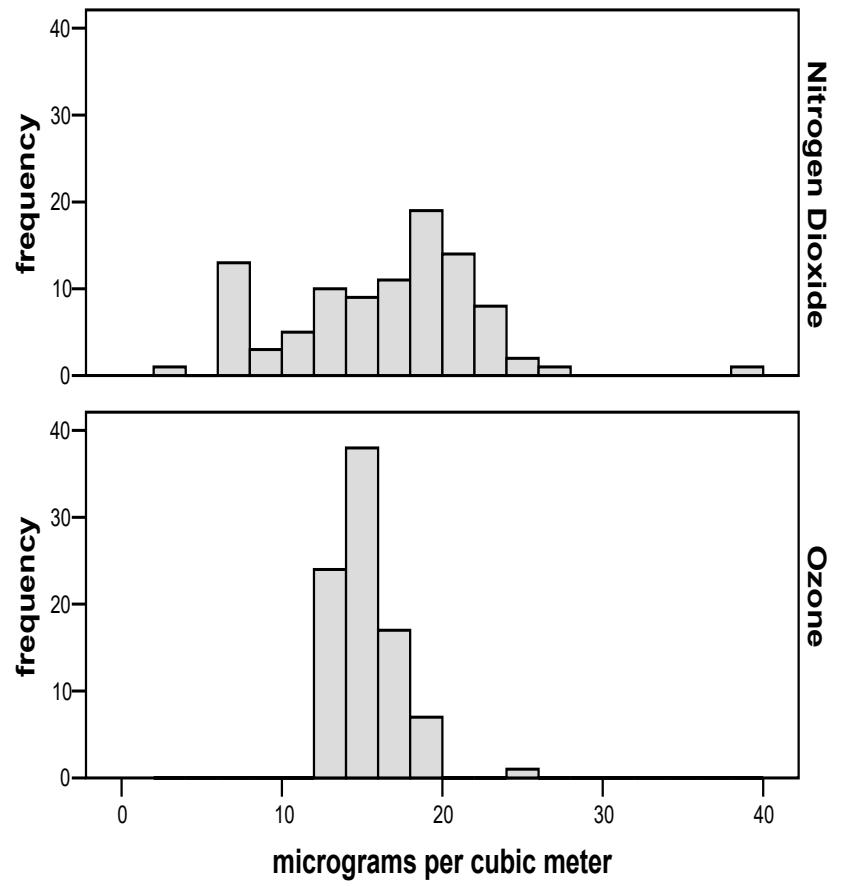

Figure 4. The estimated dose of $\mathrm{NO}_{2}$ and $\mathrm{O}_{3}$ for mothers enrolled in the study.

Table 3. Descriptive statistics (minimum, maximum, mean, and std. deviation) of trace element levels determined in tree bark (ppm).

\begin{tabular}{ccccc}
\hline Elements & Minimum & Maximum & Mean & Std. Deviation \\
\hline $\mathrm{Al}$ & 66.71 & 3873.10 & 571.52 & 500.98 \\
$\mathrm{Ba}$ & 59.55 & 1736.03 & 325.65 & 219.68 \\
$\mathrm{Ca}$ & 9985.05 & $39,883.30$ & $25,167.06$ & 4984.49 \\
$\mathrm{Cl}$ & 29.59 & 772.51 & 144.19 & 64.43 \\
$\mathrm{Cu}$ & 3.97 & 7.44 & 4.61 & 0.39 \\
$\mathrm{Fe}$ & 115.79 & 3630.08 & 644.44 & 465.86 \\
$\mathrm{~K}$ & 540.46 & 8167.26 & 1998.30 & 904.04 \\
$\mathrm{Mg}$ & 496.37 & 4442.16 & 1405.33 & 462.27 \\
$\mathrm{Mn}$ & 18.48 & 1487.87 & 113.26 & 142.33 \\
$\mathrm{Na}$ & 8.05 & 22.20 & 16.89 & 1.95 \\
$\mathrm{P}$ & 367.18 & 1682.65 & 738.05 & 171.59 \\
$\mathrm{Rb}$ & 7.04 & 24.76 & 12.28 & 1.83 \\
$\mathrm{~S}$ & 805.46 & 3699.55 & 1842.72 & 433.43 \\
$\mathrm{Sr}$ & 27.74 & 159.26 & 78.75 & 17.63 \\
$\mathrm{Zn}$ & 10.71 & 126.39 & 55.20 & 23.33 \\
\hline
\end{tabular}


Table 4 presents the results of the factor analysis that considered the elemental composition of tree bark. Four factors were identified that explained $82.8 \%$ of the variability. Factor $1(\mathrm{Ba}, \mathrm{Fe}, \mathrm{Al}, \mathrm{K}, \mathrm{P}$, $\mathrm{Cu}, \mathrm{Rb}$, and $\mathrm{Zn})$ and factor $2(\mathrm{Mg}, \mathrm{Mn}$, and $\mathrm{S})$ were composed of trace elements associated with traffic emissions and soil suspension [31,32].

Table 4. Rotated matrix solution of elemental composition based on tree bark bioaccumulation studies.

\begin{tabular}{ccccc}
\hline \multicolumn{5}{c}{ COMPONENT MATRIX } \\
\hline ELEMENTS & Factor 1 & Factor 2 & Factor 3 & Factor 4 \\
\hline CU & 0.686 & 0.140 & 0.485 & -0.167 \\
CA & -0.362 & -0.621 & 0.339 & 0.485 \\
K & 0.773 & 0.039 & 0.542 & -0.045 \\
CL & 0.426 & 0.240 & 0.290 & -0.462 \\
S & 0.298 & 0.582 & 0.459 & 0.442 \\
P & 0.760 & 0.071 & 0.482 & 0.080 \\
AL & 0.786 & -0.074 & -0.552 & 0.184 \\
MG & -0.224 & 0.794 & -0.014 & -0.324 \\
NA & -0.568 & -0.674 & 0.336 & -0.131 \\
BA & 0.844 & 0.083 & -0.437 & 0.206 \\
SR & -0.275 & 0.412 & 0.425 & 0.711 \\
RB & 0.549 & -0.298 & 0.468 & -0.278 \\
ZN & 0.519 & -0.722 & 0.017 & 0.208 \\
MN & -0.333 & 0.731 & -0.057 & 0.157 \\
FE & 0.808 & -0.003 & -0.536 & 0.192 \\
\hline
\end{tabular}

Extraction Method: Principal Component Analysis.

Table 5 shows the sensitivity analysis of the associations between estimates of air pollution and prematurity risk. Factor 1 was the only factor that exhibited robust dose-dependent associations with prematurity. The interaction term between high $\mathrm{NO}_{2}$ (fourth quartile) and low $\mathrm{O}_{3}$ (first quartile), the history of hypertension, urinary and syphilis infection during gestation, and the late onset of prenatal care exhibited significant positive risks for prematurity while low $\mathrm{O}_{3}$ (first quartile) was protective after controlling for the age of the mother and smoking. The associations of the estimators of air pollution exposure and risk of prematurity were sufficiently robust to remain stable across different model specifications.

Table 5. Multivariate logistic model with preterm and variables related to air pollution, the characteristics of mothers, and the onset of prenatal assistance.

\begin{tabular}{cccccc}
\hline Models & Variables & Exp (B) & $p$ & Lower CI 95\% & Upper CI 95\% \\
\hline \multirow{4}{*}{ Model 1_Pollutants } & Low NO $\mathrm{NO}_{2}$ & 1.03 & 0.98 & 0.76 & 1.33 \\
& Low O & 0.50 & 0.001 & 0.36 & 0.69 \\
& Factor 1 (level 2) & 0.91 & 0.60 & 0.65 & 1.28 \\
& Factor 1 (level 3) & 1.51 & 0.02 & 1.08 & 2.12 \\
& Factor 1 (level 4) & 1.73 & 0.004 & 1.19 & 2.50 \\
\hline & Low NO & 0.99 & 0.96 & 0.75 & 1.32 \\
Model 2-Pollutants & Low O O & 0.51 & 0.001 & 0.37 & 0.70 \\
and mothers' & Factor 1 (level 2) & 0.89 & 0.53 & 0.64 & 1.26 \\
characteristics & Factor 1 (level 3) & 1.52 & 0.02 & 1.08 & 2.13 \\
& Factor 1 (level 4) & 1.72 & 0.004 & 1.18 & 2.49 \\
& Mother's age (<19 y) & 1.50 & 0.14 & 0.87 & 2.58 \\
& Mother's age (>34 y) & 1.10 & 0.47 & 0.85 & 1.43 \\
& High school level & 1.20 & 0.21 & 0.90 & 1.60 \\
& University level & 1.32 & 0.14 & 0.91 & 1.90 \\
\hline
\end{tabular}


Table 5. Cont.

\begin{tabular}{cccccc}
\hline Models & Variables & Exp (B) & $p$ & Lower CI 95\% & Upper CI 95\% \\
\hline & Low NO $\mathrm{NO}_{2}$ & 0.86 & 0.33 & 0.63 & 1.16 \\
& Low $\mathrm{O}_{3}$ & 0.46 & 0.001 & 0.33 & 0.65 \\
& Factor 1 (level 2) & 0.87 & 0.43 & 0.60 & 1.24 \\
& Factor 1 (level 3) & 1.60 & 0.01 & 1.12 & 2.29 \\
& Factor 1 (level 4) & 1.65 & 0.01 & 1.11 & 2.45 \\
& Mother's age (<19 y) & 1.41 & 0.45 & 0.79 & 2.51 \\
Mother's age (>34 y) & 1.11 & 0.62 & 0.84 & 1.47 \\
Model 3-Pollutants, & High school level & 1.25 & 0.16 & 0.92 & 1.70 \\
mothers' & University level & 1.52 & 0.05 & 0.99 & 1.80 \\
sharacteristics, & Public assistance & 1.34 & 0.05 & 1.00 & 2.98 \\
and prenatal disease & Use of drugs & 1.13 & 0.80 & 0.43 & 1.22 \\
& Smoking & 0.79 & 0.28 & 0.51 & 2.50 \\
& Alcohol consumption & 0.91 & 0.70 & 0.55 & 2.38 \\
& Urinary infection & 1.69 & 0.001 & 1.31 & 13.05 \\
& Hypertension & 1.71 & 0.001 & 1.23 & 2.39 \\
& Syphilis & 5.02 & 0.001 & 1.93 & 2.98 \\
\hline
\end{tabular}

Low $\mathrm{O}_{3}$ is the first quartile and comprises values $\leq 14.2 \mu \mathrm{g} / \mathrm{m}^{3}$ and high $\mathrm{NO}_{2} \geq 16.4 \mu \mathrm{g} / \mathrm{m}^{3}$.

\section{Discussion}

The present study detected significant associations between markers of exposure to ambient air pollution and the risk of premature births. Based on these results, variations in exposure in the microscale range determined by passive methods had an important influence on prematurity risk, which reinforces the concept that gestation represents a time window of extreme vulnerability to air pollution.

Although air pollution standards have been established by health authorities, it is quite possible that a safety threshold does not exist for airborne toxics. Because of their conspicuous presence in the urban environment, genetic, epigenetic profiles as well as comorbidities and social and economic determinants may increase the vulnerability of the exposed population to a point that even low concentrations may determine adverse health effects [33-35].

One of the main challenges in determining the adverse effects of air pollution on health, mainly in underprivileged populations, is the adequate characterization of small-scale variations of exposure [36,37]. In such context, we designed the present investigation by employing methods to capture small-scale variations of air contaminants and social and economic characteristics and aiming to determine whether air pollution has an independent role in determining higher risk for prematurity.

Epidemiologic studies conducted in different areas have reported significant associations between air pollution and prematurity [38]. Using variations in air pollution in the time domain, the period of gestation being more prone to the effects of air pollution exposure was explored by Rich et al. [39] and Giorgis-Allemand et al. [40]. The methods of pollution evaluation used in our investigation did not allow time resolution since they represented integrated measures across a period of time. Passive tubes averaged 10 days and four seasons while tree bark had a longer memory of trace element accumulation. The lack of time resolution was partly compensated by the high spatial resolution because the results allowed the determination of areas with different levels of contamination. Therefore, these determinations of exposure were rather qualitative but were useful to define areas with high and low pollution within the areas of study. Even considering the limitations of the exposure assessment, the results indicated that areas with higher levels of air pollution exhibited significantly higher risks of premature birth. The magnitude of the observed risks and the corresponding levels of significance 
were stable when different sets of controlling variables were included in the multivariate models. These findings suggest that the observed associations are sufficiently robust to model specifications that will provide additional support to our results.

It is important to notice that the measured concentrations of $\mathrm{NO}_{2}$ and $\mathrm{O}_{3}$ exhibited low concentrations of both contaminants, which was previously reported in other studies that focused on indoor air pollution conducted in São Paulo [41]. The same observation-low levels of pollution of $\mathrm{NO}_{2}$ and $\mathrm{O}_{3}$-were observed in a small pregnancy cohort conducted by our group [18]. It is important to mention that most of our population sample has their residencies in areas such as slums. In such a setting, the traffic is virtually negligible in the small pathways that cross the community. Thus, because of the distance from major roads, the concentrations of gaseous pollutants are probably attenuated by dispersion and dilution [28], but we cannot exclude the contribution of additional sources of indoor $\mathrm{NO}_{2}$. Butane, for instance, is the most used fuel for home cooking in our population and may have contributed, to some extent, to the observed $\mathrm{NO}_{2}$ levels detected by our passive tubes. However, our results indicate that traffic emissions are a significant source of air pollution in our study scenarios since the elements measured in tree bark are indicative of a significant presence of automotive emissions [31,32]. Since UV radiation is virtually absent in the indoor environment, we interpreted $\mathrm{O}_{3}$ levels measured by the passive tubes as the result of outdoor photochemical processes, which is likely derived from traffic sources. Lastly, filters measured the accumulated concentration from seven to 10 days, which is an event that could have dampened the variation of ambient concentrations of gaseous pollutants. Moreover, the initial idea-to measure the outdoor levels-was not possible since the filters were systematically vandalized. Thus, we had to install the filters indoors. This is a situation that most probably reduced even further the concentrations especially that of $\mathrm{O}_{3}$.

The results suggest that particles (estimated by tree bark accumulation) and photochemical pollutants involved in the photochemical cycle (estimated by $\mathrm{O}_{3}$ and $\mathrm{NO}_{2}$ passive tubes) play a role in the pathogenesis of premature birth (Table 5). The present study was not designed to investigate causal mechanisms. However, previous reports in the literature have described the potential mechanisms by which air pollution favors prematurity [42]. Placental insufficiency [14,15], trans placental transport of toxins [16], constriction of blood vessels in the umbilical cord [17], and alterations of placental flow [18] are examples of events associated with exposure to ambient levels of air pollution. Recent animal studies conducted by our group indicate that exposure to ambient levels of air pollution reduces the expression of angiotensin in placental tissue, which affects the invasion of trophoblast and, thus, reduces fetal-maternal interaction. The previously mentioned alterations, acting alone or in combination, indicate that exposure to air pollutants may create an unfavorable milieu for the fetuses up to the point of predisposition to prematurity [19].

This study also confirmed some characteristics classically associated with premature birth including urinary infection, arterial hypertension, and the late onset of prenatal care. In this context, our results indicate that a broad characterization of the urban environment including physical, social, cultural, and economic parameters is necessary to establish sound and efficient public policies that aim to reduce prematurity.

\section{Conclusions}

In conclusion, our results indicate that air pollution represents a significant risk for premature births. Intra-urban variations in exposure even at the scale of hundreds of meters may modify the risk. Additionally, this study suggests that low-cost techniques may be used to track the spatial variability of exposure and may be used in areas devoid of conventional pollution monitoring systems.

Author Contributions: S.R.D.M.S., L.V.B., C.R.L., M.A.F., E.d.A.B., R.T.I.B., R.C.d.O., and P.H.N.S. conceived the study. S.R.D.M.S., L.V.B., and R.T.I.B. sampled preterm and control babies and passive filters. M.A.F. and E.d.A.B. geo-coded babies' addresses. L.V.B. performed spatial cluster analysis. R.C.d.O. and P.H.N.S. estimated air pollution exposure. S.R.D.M.S. led mothers' interviews. S.R.D.M.S., L.V.B., and P.H.N.S. analyzed the data. 
S.R.D.M.S., L.V.B., C.R.L., M.A.F., E.d.A.B., R.T.I.B., R.C.d.O., and P.H.N.S. contributed to the interpretation of the results. S.R.D.M.S. and P.H.N.S. wrote the first draft of the manuscript. L.V.B., C.R.L., M.A.F., E.d.A.B., R.T.I.B., and R.C.d.O. contributed and reviewed the final manuscript.

Funding: This study received funding from the Brazilian National Council of Scientific and Technological Development (CNPq) (MCTI/CNPq/MS/SCME/Decit/Bill and Melinda Gates Foundation n ${ }^{0}$ 401616/2013-4).

Conflicts of Interest: The authors declare that they have no competing financial interests.

Ethical Approval: The Ethics Committee of the Secretary of Health of the Municipality of São Paulo (CAEE 26132714.1.0000.0086) approved the present study.

\section{References}

1. Goldenberg, R.L.; Culhane, J.F.; Iams, J.D.; Romero, R. Epidemiology and causes of preterm birth. Lancet 2008, 371, 75-84. [CrossRef]

2. Gravett, M.G.; Rubens, C.E.; Nunes, T.M. Global report on preterm birth and stillbirth (2 of 7): Discovery science. BMC Pregnancy Childbirth 2010, 10. [CrossRef] [PubMed]

3. Beck, S.; Wojdyla, D.; Say, L.; Betran, A.P.; Merialdi, M.; Requejo, J.H.; Rubens, C.; Menon, R.; Van Look, P.F. The worldwide incidence of preterm birth: A systematic review of maternal mortality and morbidity. Bull. World Health Organ. 2010, 88, 31-38. [CrossRef] [PubMed]

4. Henderson, J.J.; McWilliam, O.A.; Newnham, J.P.; Pennell, C.E. Preterm birth aetiology 2004-2008. Maternal factors associated with three phenotypes: Spontaneous preterm labour, preterm pre-labour rupture of membranes and medically indicated preterm birth. J. Matern. Fetal Neonatal Med. 2012, 25, $642-647$. [CrossRef] [PubMed]

5. Visentin, S.; Grumolato, F.; Nardelli, G.B.; Di Camillo, B.; Grisan, E.; Cosmi, E. Early origins of adult disease: Low birth weight and vascular remodeling. Atherosclerosis 2014, 237, 391-399. [CrossRef] [PubMed]

6. Li, S.; Zhang, M.; Tian, H.; Liu, Z.; Yin, X.; Xi, B. Preterm birth and risk of type 1 and type 2 diabetes: Systematic review and meta-analysis. Obes. Rev. 2014, 15, 804-811. [CrossRef] [PubMed]

7. O'Reilly, M.; Sozo, F.; Harding, R. Impact of preterm birth and bronchopulmonary dysplasia on the developing lung: Long-term consequences for respiratory health. Clin. Exp. Pharmacol. Physiol. 2013, 40, 765-773. [CrossRef] [PubMed]

8. Bayman, E.; Drake, A.J.; Piyasena, C. Prematurity and programming of cardiovascular disease risk: A future challenge for public health. Arch. Dis. Child. Fetal Neonatal Ed. 2014, 99, F510-F514. [CrossRef] [PubMed]

9. Huang, J.; Zhu, T.; Qu, Y.; Mu, D. Prenatal, perinatal and neonatal risk factors for intellectual disability: A systemic review and meta analysis. PLoS ONE 2016, 11, e0153655. [CrossRef] [PubMed]

10. Burris, H.H.; Baccarelli, A.A.; Wright, R.O.; Wright, R.J. Epigenetics: Linking social and environmental exposures to preterm birth. Pediatr. Res. 2016, 79, 136-140. [CrossRef] [PubMed]

11. Stieb, D.M.; Chen, L.; Eshoul, M.; Judek, S. Ambient air pollution, birth weight and preterm birth: A systematic review and meta-analysis. Environ. Res. 2012, 117, 100-111. [CrossRef] [PubMed]

12. Malley, C.S.; Kuylenstierna, J.C.; Vallack, H.W.; Henze, D.K.; Blencowe, H.; Ashmore, M.R. Preterm birth associated with maternal fine particulate matter exposure: A global, regional and national assessment. Environ. Int. 2017, 101, 173-182. [CrossRef] [PubMed]

13. Shah, P.S.; Balkhair, T.; Knowledge Synthesis Group on Determinants of Preterm/LBW births. Air pollution and birth outcomes: A systematic review. Environ. Int. 2011, 37, 498-516. [CrossRef] [PubMed]

14. Veras, M.M.; Damaceno-Rodrigues, N.R.; Caldini, E.G.; Ribeiro, A.A.M.; Mayhew, T.M.; Saldiva, P.H.; Dolhnikoff, M. Particulate urban air pollution affects the functional morphology of mouse placenta. Biol. Reprod. 2008, 79, 578-584. [CrossRef] [PubMed]

15. Kampa, M.; Castanas, E. Human health effects of air pollution. Environ. Pollut. 2008, 151, 362-367. [CrossRef] [PubMed]

16. Van den Hooven, E.H.; Pierik, F.H.; de Kluizenaar, Y.; Hofman, A.; van Ratingen, S.W.; Zandveld, P.Y.; Russcher, H.; Lindemans, J.; Miedema, H.M.; Steeqers, E.A.; et al. Air pollution exposure and markers of placental growth and function: The generation R study. Environ. Health Perspect. 2012, 120, 1753-1759. [CrossRef] [PubMed] 
17. Novack, L.; Yitshak-Sade, M.; Landau, D.; Kloog, I.; Sarov, B.; Karakis, I. Association between ambient air pollution and proliferation of umbilical cord blood cells. Environ. Res. 2016, 151, 783-788. [CrossRef] [PubMed]

18. Carvalho, M.A.; Bernardes, L.S.; Hettfleisch, K.; Pastro, L.D.; Vieira, S.E.; Saldiva, S.R.; Saldiva, P.H.; Francisco, R.P. Associations of maternal personal exposure to air pollution on fetal weight and fetoplacental Doppler: A prospective cohort study. Reprod. Toxicol. 2016, 62, 9-17. [CrossRef] [PubMed]

19. Vadillo-Ortega, F.; Osornio-Vargas, A.; Buxton, M.A.; Sánchez, B.N.; Rojas-Bracho, L.; Viveros-Alcaráz, M.; Castillo-Castrejón, M.; Beltrán-Montoya, J.; Brown, D.G.; O’Neill, M.S. Air pollution, inflammation and preterm birth: A potential mechanistic link. Med Hypotheses 2014, 82, 219-224. [CrossRef] [PubMed]

20. Hajat, A.; Hsia, C.; O'Neill, M.S. Socioeconomic disparities and air pollution exposure: A global review. Curr. Environ. Health Rpt. 2015, 2, 440. [CrossRef] [PubMed]

21. Tu, J.; Tu, W.; Tedders, S.H. Spatial variations in the associations of term birth weight with ambient air pollution in Georgia, USA. Environ. Int. 2016, 92, 146-156. [CrossRef] [PubMed]

22. Coker, E.; Liverani, S.; Su, J.G.; Molitor, J. Multi-pollutant modeling through examination of susceptible subpopulations using profile regression. Curr. Environ. Health Rep. 2018, 5, 59-69. [CrossRef] [PubMed]

23. Passini, R., Jr.; Cecatti, J.G.; Lajos, G.J.; Tedesco, R.P.; Nomura, M.L.; Dias, T.Z.; Haddad, S.M.; Rehder, P.M.; Pacagnella, R.C.; Costa, M.L.; et al. Brazilian Multicentre Study on Preterm Birth (EMIP): Prevalence and factors associated with spontaneous preterm birth. PLoS ONE 2014, 9, e109069. [CrossRef] [PubMed]

24. Institute of Medicine. Preterm Birth: Causes, Consequences, and Prevention; Behrman, R.E., Butler, A.S., Eds.; National Academies Press: Washington, DC, USA, 2004.

25. SaTScanTM, v9.3; Boston, MA, USA, 2014. Available online: http://www.satscan.org/ (accessed on 14 October 2014).

26. Novaes, P.; Saldiva, P.H.N.; Kara-José, N.; Macchione, M.; Matsuda, M.; Racca, L.; Berra, A. Ambient levels of air pollution induce goblet-cell hyperplasia in human conjunctival epithelium. Environ. Health Perspect. 2007, 115, 1753-1756. [CrossRef] [PubMed]

27. Saldiva de André, C.D.; de André, P.A.; Rocha, F.M.; Saldiva, P.H.N.; Oliveira, R.C.; Singer, J.M. Reliability of reflectance measures in passive filters. Atmos. Environ. 2014, 92, 178e181. [CrossRef]

28. Carneiro, M.F.H.; Ribeiro, F.Q.; Fernandes-Filho, F.N.; Lobo, D.J.A.; Barbosa, F.; Rhoden, C.R.; Mauad, T.; Saldiva, P.H.N.; Carvalho-Oliveira, R. Pollen abortion rates, nitrogen dioxide by passive diffusive tubes and bioaccumulation in tree barks are effective in the characterization of air pollution. Environ. Exp. Bot. 2011, 72, 272-277. [CrossRef]

29. Amato-Lourenco, L.F.; Lobo, D.J.A.; Guimarães, E.T.; Moreira, T.C.L.; Carvalho-Oliveira, R.; Saiki, M.; Saldiva, P.H.N.; Mauad, T. Biomonitoring of genotoxic effects and elemental accumulation derived from air pollution in community urban gardens. Sci. Total Environ. 2017, 575, 1438-1444. [CrossRef] [PubMed]

30. Carvalho-Oliveira, R.; Amato-Lourenço, L.F.; Moreira, T.C.; Silva, D.R.R.; Vieira, B.D.; Mauad, T.; Saiki, M.; Saldiva, P.H.N. Effectiveness of traffic-related elements in tree bark and pollen abortion rates for assessing air pollution exposure on respiratory mortality rates. Environ. Int. 2017, 99, 161-169. [CrossRef] [PubMed]

31. Moreira, T.C.L.; de Oliveira, R.C.; Amato-Lourenço, L.F.; Kang, C.M.; Saldiva, P.H.N.; Saiki, M. Intra-urban biomonitoring: Source apportionment using tree barks to identify air pollution sources. Environ. Int. 2016, 91, 271-275. [CrossRef] [PubMed]

32. Moreira, T.C.L.; Amato-Lourenço, L.F.; da Silva, G.T.; Saldiva de André, C.D.; de André, P.A.; Barrozo, L.V.; Singer, J.M.; Saldiva, P.H.N.; Saiki, M.; Locosselli, G.M. The use of tree barks to monitor traffic related air pollution: A case study in São Paulo-Brazil. Front. Environ. Sci. 2018, 6, 72. [CrossRef]

33. Schwartz, J.; Laden, F.; Zanobetti, A. The concentration-response relation between pm (2.5) and daily deaths. Environ. Health Perspect. 2002, 110, 1025. [CrossRef] [PubMed]

34. Makri, A.; Stilianakis, N.I. Vulnerability to air pollution health effects. Int. J. Hyg. Environ. Health 2008, 211, 326-336. [CrossRef] [PubMed]

35. Chen, G.; Guo, Y.; Abramson, M.J.; Williams, G.; Li, S. Exposure to low concentrations of air pollutants and adverse birth outcomes in Brisbane, Australia, 2003-2013. Sci. Total Environ. 2018, 622, 721-726. [CrossRef] [PubMed]

36. Brindley, P.; Maheswaran, R.; Pearson, T.; Wise, S.; Haining, R.P. Using modeled air pollution data for health surveillance. In GIS in Public Health Practice; Maheswaran, R., Craglia, M., Eds.; CRC Press: Boca Raton, FL, USA, 2004; pp. 125-150. 
37. HEADLAMP; World Health Organization; Office of Global and Integrated Environmental Health; United Nations Environment Programme \& United States. Environmental Protection Agency. Linkage Methods for Environment and Health Analysis: General Guidelines: A Report of the Health and Environment Analysis for Decision-making (HEADLAMP) Project. Available online: http:/ / www.who.int/iris/handle/10665/62988 (accessed on 17 September 2018).

38. Fleischer, N.L.; Merialdi, M.; van Donkelaar, A.; Vadillo-Ortega, F.; Martin, R.V.; Betran, A.P.; Souza, J.P. Outdoor air pollution, preterm birth, and low birth weight: Analysis of the world health organization global survey on maternal and perinatal health. Environ. Health Perspect. 2014, 122, 425-430. [CrossRef] [PubMed]

39. Rich, D.Q.; Liu, K.; Zhang, J.; Thurston, S.W.; Stevens, T.P.; Pan, Y.; Kane, C.; Weinberger, B.; Ohman-Strickland, P.; Woodruff, T.J.; Duan, X.; et al. Differences in birth weight associated with the 2008 Beijing Olympics air pollution reduction: Results from a natural experiment. Environ. Health Perspect. 2015, 123, 880-887. [CrossRef] [PubMed]

40. Giorgis-Allemand, L.; Pedersen, M.; Bernard, C.; Aguilera, I.; Beelen, R.M.; Chatzi, L.; Cirach, M.; Danileviciute, A.; Dedele, A.; van Eijsden, M.; et al. The influence of meteorological factors and atmospheric pollutants on the risk of preterm birth. Am. J. Epidemiol. 2017, 185, 247-258. [CrossRef] [PubMed]

41. Vieira, S.E.; Stein, R.T.; Ferraro, A.A.; Pastro, L.D.; Pedro, S.S.; Lemos, M.; da Silva, E.R.; Sly, P.D.; Saldiva, P.H. Urban air pollutants are significant risk factors for asthma and pneumonia in children: The influence of location on the measurement of pollutants. Arch. Bronconeumol. 2012, 48, 389-395. [CrossRef] [PubMed]

42. Soto, S.F.; Melo, J.O.; Marchesi, G.D.; Lopes, K.L.; Veras, M.M.; Oliveira, I.B.; Souza, R.M.; de Castro, I.; Furukawa, L.N.S.; Saldiva, P.H.N.; et al. Exposure to fine particulate matter in the air alters placental structure and the renin-angiotensin system. PLoS ONE 2017, 12, e0183314. [CrossRef] [PubMed]

(C) 2018 by the authors. Licensee MDPI, Basel, Switzerland. This article is an open access article distributed under the terms and conditions of the Creative Commons Attribution (CC BY) license (http:// creativecommons.org/licenses/by/4.0/). 